\title{
Differences in Anthropometric Characteristics, Somatotype Components, and Functional Abilities Among Young Elite Kosovo Soccer Players Based on Team Position
}

\author{
Diferencias en las Características Antropométricas, los Componentes del Somatotipo y las Habilidades \\ Funcionales Entre Jóvenes Futbolistas de Élite de Kosovo Basadas en la Posición en el Equipo
}

\author{
Malsor Gjonbalaj'; ${ }^{1}$ Georgi Georgiev² \& Dusko Bjelica ${ }^{3}$
}

GJONBALAJ, M.; GEORGIEV, G. \& BJELICA, D. Differences in anthropometric characteristics, somatotype components, and functional abilities among young elite Kosovo soccer players based on the team position. Int. J. Morphol., 36(1):41-47, 2018.

SUMMARY: The height, weight, diameters, volumes and skin folds were measured on a sample of 242 young soccer players from the Republic of Kosovo and therefore, the body composition, somatotype components, BMI index and maximum oxygen consumption. These were indirectly measured in order to determine their common morphological and functional features and analyze specificity i.e., the likely differences based on the playing positions (goalkeepers, defense, middle players and attackers). Within the statistical analysis, the basic descriptive statistical parameters were calculated, and a multivariate and univariate analysis of variance and post-hoc analysis were applied. Goalkeepers have statistically significantly higher body height and humeral breadth, and lower values of maximum oxygen consumption, in comparison to players who play the other positions on the team and higher body weight regarding the players who play in the middle and the attackers. Defense players have statistically significant higher body weight than the middle players. In the other anthropometric measures and somatotype components, there are no statistically significant differences among the players who play on different positions in the team. The achieved results could serve as normative morphological and functional indicators for regular sports medical examinations of young soccer players in the Republic of Kosovo. They could also be used as a template for comparison of the morphological and functional data of young soccer players at similar level in different countries.

KEY WORDS: Body composition; Morphological and Functional Indicators; Footballers.

\section{INTRODUCTION}

Success in sports is directly related to the specific anthropometric characteristics, body composition and somatotype components (Carter \& Heath, 1990). During the football match (90 minutes), the movements of the players are characterized with high intensity, short actions and breaks with different duration. Soccer players should have the optimum combination of technical, tactical, physical characteristics (e.g. somatotype), and mental and motivational predispositions (Bangsbo, 1994) among other sports characteristics in order to be successful. Therefore, for football coaches, managers, sports physiotherapist, scientists, an in-depth understanding of the determinants of success, such as the specific anthropometric characteristics of players, may be important. Some research suggest that there are specifics of anthropometric characteristics of the players who play on different positions in the team (Bale, 1986; Rienzi et al., 2000; Gil et al., 2007). Goalkeepers are taller than the players who play in the middle, such as central defensive and offensive players (Reilly et al., 2000; Gil et al.). Similar results were obtained in some studies that researched the specifics of anthropometric characteristics regarding the position at which the player is, as follows: Australian football (Pyne et al., 2006), Gaelic soccer (McIntyre \& Hall, 2005), rugby (Bale), American football (Bale; Garstecki et al., 2004), Brazilian football (Fidelix et al., 2014), Ethiopian football (Hailu et al., 2016; Ibrahim et al., 2017) and Macedonian football (Gontarev et al., 2016).

The somatotype components could be measured on the basis of certain anthropometric measures (Carter \&

\footnotetext{
${ }^{1}$ University of Kosovo, Faculty of Physical Education and Sport, Pristina, Kosovo.

${ }^{2}$ University Ss. Cyril and Methodius, Faculty of Physical Education, Sport and Health, Skopje, Republic of Macedonia.

${ }^{3}$ University of Montenegro, Faculty for Sport and Physical Education, Niksic, Montenegro.
} 
Heath; Reilly \& Marfell-Jones, 2003). A somatotype can be defined in terms of its three components: endomorphy, mesomorphy and ectomorphy (Carter \& Heath). The combination of these three physical parameters allows the athlete to be classified in different somatotype category. Generally, mesomorphic component dominates at soccer players, and their somatotype category is balanced mesomorhpic such as 2.5-5.0-2.5 (Carter \& Heath; Rienzi et al.).

Having in mind that specialization begins at early age, the understanding of morphological features for each position of the team is pretty much important for coaches, sports physicians, and scientists. The purpose of this paper was to determine the morphological and functional characteristics in soccer players who play in the Junior Super League in Kosovo and to determine the possible differences in the monitored characteristics, regarding the position which the player has.

\section{MATERIAL AND METHOD}

Subjects. The study was conducted in the National Center for Sport Medicine (NCSM) in Prishtina, where all active athletes from the Republic of Kosovo are obliged to undergo regular medical and sports examination. Measurements are made in the month of February 2017, when players have the obligatory sports medical examinations.

The sample consisted of 242 young soccer players who play in the best clubs of Junior Super League in Kosovo (U19), age 19 to 21 years old and have at least 5 years sport experience. The sample was divided into four (4) different groups according to the position which players have in the team: 20 goalkeepers $(\mathrm{n}=20) ; 84$ defense players $(\mathrm{n}=84) ; 88$ midfielders $(\mathrm{n}=88)$ and 50 forwards $(\mathrm{n}=50)$. The respondents were treated in accordance with the recommendations of the Helsinki Declaration.

Protocols and equipment. All measurements were conducted by highly skilled, trained and experienced sports doctors. Height and body weight were measured using stadiometer (Seca, Leicester, UK) and electronic weighing machine (HD-351, Tanita, Illinois, USA). Skin folds were measured using John Bull calipers. The volumes are measured with a standard flexible measuring tape, while the diameters are measured using sliding calipers (GPMc).

Besides height and weight, the following anthropometric measures were also measured: two diameters (femoris breadth and humeral breadth); two circumferences (biceps girth and calf girthas), as well as four skin folds (triceps, subscapular, supraspinale and calf skinfold).

The maximum oxygen consumption was measured using standard treadmill exercise testing according to the Bruce protocol which is a sub-maximal treadmill test. Bruce test consists of multiple stages of progressively increasing workloads, which should be performed until the examinee reaches his sub-maximal heart rate. The test includes 7 stages, each lasting for 3 minutes and with each subsequent stage the speed and the inclination of the track is significantly increased. $\mathrm{VO}_{2 \max }$ is calculated from the Bruce nomogram using the exercise time (ET - duration of the test expressed in minutes) and the sex of the examinee.

Statistical Methods. The data were analyzed using the Statistical Package for Social Sciences software (SPSS, v. 22.0 for WINDOWS; SPSS Inc., Chicago, IL, USA), and values of $p<0.05$ were considered statistically significant. Basic descriptive parameters of anthropometric variables were calculated: arithmetic mean (Mean), standard deviation (SD), minimum and maximum value of the results registered (MIN, MAX). The normality of distribution was verified following the Kolmogor-Smirnov test. The between positions differences were computed by the multivariate and univariate analyses of variance (ANOVA) and LSD test was used as a post-hoc test.

\section{RESULTS}

Basic descriptive statistical parameters of anthropometric measures, somatotype components and maximum oxygen consumption of the whole group of respondents are shown in Table I. The results of the analysis indicate that the majority of applied variables are normally distributed.

On multivariate level, statistically significant differences in the researched variables between players who play in different positions on the team are not determined (Table II). On univariate level (Table II), statistics between group differences in anthropometric measures, somatotype components and maximum oxygen consumption between players who play in different positions on the team are determined in the variables: height $(F=3.60 ; p=.014)$, weight $(\mathrm{F}=4.09 ; \mathrm{p}=.007)$, calf thickness $(\mathrm{F}=3.00 ; \mathrm{p}=$. 031), humeral width $(\mathrm{F}=3.24 ; \mathrm{p}=.023)$ and $\mathrm{VO}_{2 \text { max }}(\mathrm{ml} /$ $\min / \mathrm{kg})(\mathrm{F}=3.79 ; \mathrm{p}=.011)$. 
The differences between positions are obtained by post-hoc analysis of variance (Table III). The results of the analysis show that there are differences in morphological profile among the players who play in different positions on the team. Goalkeepers have statistically significant higher body height and humeral breadth, and lower values of the maximum oxygen consumption in comparison to players who play in other positions on the team and more weight regarding the players who play in the middle and forward. Defensive players have statisticaly significant higher body weight in comparison to the middle players. Statistically significant differences among the players who play in different positions on the team are not determined in other anthropometric measures and somatotype components.

Table I. Basic statistical parameters of morphological characteristics of soccer players.

\begin{tabular}{lcccc}
\hline Variables & Mean & SD & Min & Max \\
\hline Height & 177.90 & 6.09 & 157.30 & 192.80 \\
Weight & 68.94 & 7.44 & 48.00 & 92.00 \\
BMI & 21.77 & 2.02 & 15.32 & 28.99 \\
Biceps girth & 27.24 & 2.18 & 20.30 & 36.00 \\
Calf girth & 36.09 & 2.02 & 30.00 & 43.30 \\
Femoris breadth & 9.63 & 0.44 & 8.40 & 11.20 \\
Humeral breadth & 6.79 & 0.38 & 5.90 & 8.10 \\
Triceps skinfold & 7.99 & 2.82 & 3.80 & 19.20 \\
Subscapular skinfold & 8.02 & 2.34 & 5.00 & 21.20 \\
Supraspinale skinfold & 8.96 & 3.85 & 4.00 & 27.00 \\
Calf skinfold & 8.45 & 3.51 & 3.00 & 23.00 \\
Suma skinfold & 33.42 & 11.36 & 17.20 & 89.20 \\
Body fat & 11.64 & 4.28 & 4.74 & 29.64 \\
Endomorphic & 2.35 & 0.87 & 1.07 & 6.08 \\
Mesomorphic & 3.45 & 1.02 & 0.73 & 6.73 \\
Ectomorphic & 3.25 & 1.07 & 0.33 & 7.07 \\
VO ${ }_{2}$ max (ml/min/kg) & 52.64 & 5.60 & 40.30 & 68.00 \\
\hline
\end{tabular}

Table II. Results of multivariate and univariate analysis of variance.

\begin{tabular}{|c|c|c|c|}
\hline Variables & $\mathrm{F}$ & Sig. & Eta \\
\hline Height & 3.60 & .014 & .043 \\
\hline Weight & 4.09 & .007 & .049 \\
\hline BMI & 1.34 & .263 & .017 \\
\hline Biceps girth & 0.73 & .536 & .009 \\
\hline Calf girth & 3.00 & .031 & .036 \\
\hline Femoris breadth & 1.73 & .161 & .021 \\
\hline Humeral breadth & 3.24 & .023 & .039 \\
\hline Triceps skinfold & 0.24 & .872 & .003 \\
\hline Subscapular skinfold & 0.32 & .809 & .004 \\
\hline Supraspinale skinfold & 1.03 & .380 & .013 \\
\hline Calf skinfold & 0.96 & .413 & .012 \\
\hline Suma skinfold & 0.68 & .567 & .008 \\
\hline Body fat & 0.26 & .856 & .003 \\
\hline Endomorphic & 0.38 & .768 & .005 \\
\hline Mesomorphic & 0.50 & .685 & .006 \\
\hline Ectomorphic & 0.57 & .635 & .007 \\
\hline $\mathrm{VO}_{2} \max (\mathrm{ml} / \mathrm{min} / \mathrm{kg})$ & 3.79 & .011 & .046 \\
\hline Wilks'l=0.806 & Rao $\mathrm{R}=$ & & 401 \\
\hline
\end{tabular}



on the team position. Int. J. Morphol., 36(1):41-47, 2018.

Table III. Average values of morphological characteristics in soccer players according to their position in the game.

\begin{tabular}{|c|c|c|c|c|c|c|c|c|c|}
\hline \multirow{2}{*}{$\mathrm{A}$} & \multicolumn{2}{|c|}{ Goalkeepers } & \multicolumn{2}{|c|}{ Defenders } & \multicolumn{2}{|c|}{ Midfielders } & \multicolumn{2}{|c|}{ Attackers } & \multirow{2}{*}{$\begin{array}{c}\text { Post hoc pairwaise } \\
\text { comparisons }\end{array}$} \\
\hline & Mean & SD & Mean & SD & Mean & SD & Mean & SD & \\
\hline Height & 181.95 & 5.89 & 178.00 & 6.19 & 177.13 & 5.91 & 177.48 & 5.86 & $1 \& 2 ; 1 \& 3 ; 1 \& 4$ \\
\hline Weight & 73.30 & 6.27 & 69.86 & 7.26 & 67.61 & 7.43 & 67.98 & 7.53 & $1 \& 3 ; 1 \& 4 ; 2 \& 3$ \\
\hline BMI & 22.14 & 1.52 & 22.05 & 2.06 & 21.54 & 2.06 & 21.57 & 2.01 & $\mathrm{~ns}$ \\
\hline Bic eps girth & 27.44 & 2.29 & 27.48 & 2.16 & 27.01 & 2.24 & 27.15 & 2.08 & $\mathrm{~ns}$ \\
\hline Calf girth & 36.85 & 1.64 & 36.43 & 1.93 & 35.72 & 2.06 & 35.85 & 2.10 & $1 \& 3 ; 2 \& 3$ \\
\hline Femoris breadth & 9.83 & 0.45 & 9.65 & 0.44 & 9.58 & 0.43 & 9.61 & 0.43 & $1 \& 3$ \\
\hline Humeral breadth & 7.02 & 0.31 & 6.81 & 0.39 & 6.76 & 0.35 & 6.73 & 0.42 & $1 \& 2 ; 1 \& 3 ; 1 \& 4$ \\
\hline Triceps skinfold & 8.30 & 2.94 & 8.04 & 2.93 & 8.03 & 2.71 & 7.73 & 2.82 & ns \\
\hline Subsca pular skinfold & 8.36 & 2.15 & 8.14 & 2.63 & 7.89 & 2.33 & 7.93 & 1.94 & $\mathrm{~ns}$ \\
\hline Supraspinale skinfold & 9.76 & 3.25 & 9.18 & 4.45 & 8.99 & 3.89 & 8.20 & 2.72 & $\mathrm{~ns}$ \\
\hline Calf skinfold & 9.61 & 4.57 & 8.55 & 3.79 & 8.27 & 3.26 & 8.14 & 2.95 & ns \\
\hline Suma skinfold & 36.03 & 11.63 & 33.91 & 12.70 & 33.18 & 10.97 & 31.99 & 9.47 & ns \\
\hline Body fat & 12.26 & 4.23 & 11.75 & 4.59 & 11.56 & 4.20 & 11.33 & 4.00 & ns \\
\hline Endomorphic & 2.45 & 0.79 & 2.38 & 0.98 & 2.35 & 0.86 & 2.24 & 0.74 & ns \\
\hline Mesomorphic & 3.37 & 0.80 & 3.56 & 1.10 & 3.40 & 1.00 & 3.40 & 0.99 & ns \\
\hline Ectomorphic & 3.28 & 0.85 & 3.12 & 1.05 & 3.32 & 1.13 & 3.32 & 1.09 & ns \\
\hline $\mathrm{VO}_{2} \max (\mathrm{ml} / \mathrm{min} / \mathrm{kg})$ & 49.31 & 3.73 & 52.08 & 5.00 & 53.53 & 6.12 & 53.36 & 5.73 & $1 \& 2 ; 1 \& 3 ; 1 \& 4$ \\
\hline
\end{tabular}

\section{DISCUSSION}

There are a number of studies that research the anthropometric characteristics and somatotype components among top soccer players, or comparative research between elite and non-elite players.

The advantage of this study is that anthropometric and functional measurements are conducted on a relatively large sample of young elite players from the Republic of Kosovo which are selected from the best clubs. The results of this research can serve as normative values for comparison of anthropometric, somatotype and functional data of young soccer players in R. Kosovo and abroad.

So far studies suggest that anthropometric characteristics and body composition can influence the selection of athletes in many sports (Hasan et al., 2007). It is important that the athlete have adequate morphological and functional profile in order to be successful in a particular sports discipline (Ziv \& Lidor, 2009).

The average body height of Kosovian soccer players (U19) is $177.90 \mathrm{~cm}$, while body weight is $68.94 \mathrm{~kg}$. Different studies show that soccer players in national and international competitions vary in body weight, height and BMI index, depending on geographical location, ethnic and cultural influences or different style of football, dietary habits and the like. Professional and/or the top soccer players in Europe, the Middle East and South America have average body height ranging from $176.0-183.0 \mathrm{~cm}$., and a body weight that is generally lower than $80 \mathrm{~kg}$ (and is in the range between 65.6 - $78.7 \mathrm{~kg}$ ), and BMI index that ranges between 23.00-24.45 $\mathrm{kg} / \mathrm{m}^{2}$. Mean values of body height, weight and BMI index of Kosovian soccer players are higher regarding the players from Asian teams, and these values are similar to the values of players from European and South American teams (Reeves et al., 1999; Bandyopadhyay, 2007; Pluncevic-Gligoroska et al., 2014). By comparing the morphological characteristics between Kosovian soccer players and players from neighboring countries (Macedonia, Croatia and Serbia), it could be concluded that Kosovian soccer players have nearly identical body height, and slightly lower body weight and BMI regarding the players that play in Macedonia, Croatia and Serbia - $77.7 \mathrm{~kg}, 77.6 \mathrm{~kg}$ and $77.4 \mathrm{~kg}$ (Ostojic, 2000; Matkovic et al., 2003; Pluncevic-Gligoroska et al.).

Body composition is also an important factor for the success in this sport. The average amount of fat tissue among young healthy boys, who are not engaged in organized sport activity, range from $18-20 \%$ of total body weight, while the percentage of fat component in athletes is generally lower (Matkovic et al.). The lowest percentage of fat tissue from 4 to $7 \%$ was established in sportsmen-athletes who run long distances 8. Considering the specifics of the football game, it could be expected that soccer players have relatively low 
percentage of fat tissue. However, the results vary significantly and are subject to inter/intra-individual fluctuations, depending on the position, the standards of game and season (Thomas \& Reilly, 1979). The average values of the fat component in Kosovian footballers is around $11.6 \%$, which is within the value of the players from the first Brazilian league $(10.9 \%)$, Portuguese players $(10.5 \%)$ and English players $(12.4 \%)$ according to Matkovic et al. The percentage of fat component in Kosovian goalkeepers is somewhat higher, but not statistically significant in terms of the players that play on other positions in the team. A small percentage of fat component $(10.0 \%)$ was noted in Portuguese goalkeepers, however, we should have in mind the fact that the measurements were conducted during the season (Matkovic et al.). Higher values of the fat component in goalkeepers can be explained in the lower intensity of play to which the goalkeepers were exposed on the other. However, taking into account the specific movements of the goalkeeper: jumps, throws, falls, etc., it can be assumed that the lower percentage of fat tissue will contribute for more effective play. The lowest values of fat tissue that are not statistically significant are noted among forward players - players of the attack.

Generally, mesomorphic component dominates among soccer players and their somatotype category is balanced mesomorhpic (Casajús \& Aragonés, 1991; Rienzi et al.; Bandyopadhyay). It is logical that muscle building is useful to carry out the various activities during the match because these activities define the outcome of the match, for example, start on the opponent, acceleration, kicking and building the ball. In this research Kosovian footballers show ecto-mesomorhpic somatotype (2.4-3.4-3.3) and thus partially deviate in somatotype characteristics of elite players from other countries. The somatotype of Portuguese players from the first league is 2.8-5.6-2.2 (Casajús \& Aragonés), the Spanish National Team (1990 World Cup) 2.25.1-1.9 (Casajús \& Aragonés), top level Hungarian 2.15.1-2.3, and elite level South American players 2.2-5.4-2.2 (Rienzi et al.) were higher than the mesomorphy score obtained in this study. The reason for this deviation is probably conditioned by the specifics of the sample of respondents that include only young players aged 19 to 21 years. In addition to this fact is the research who analyzed the soccer players from the junior national teams from 10 different countries and found, just like Orhan et al. (2013), that somatotype values of the players were balanced mesomorphic and ectomesomorphic, on average.

By comparing the body weight of players that play in different positions on the team, it could be noted that goalkeepers are the tallest, while the attackers and middle players are on average lower by 4 centimeters. Also, it was determined that the height may affect the position of that soccer player in the team, so that taller players are mostly found to the keeper and in defense, where height is an advantage (Bangsbo; Reilly et al., 2000; Matkovic et al.). Similar results were obtained in a study of Matkovic et al. who found that Croatian goalkeepers are the tallest and heaviest, and have long arms and legs. In our research goalkeepers and defense players are also taller than the players who play in the middle and forward.

The maximum oxygen consumption of Kosovian soccer players is around $53 \mathrm{ml} / \mathrm{min} / \mathrm{kg}$. When you compare the maximum oxygen consumption in Kosovian young players with the results of international studies, we find that Kosovar athletes are at the bottom of the scale for this parameter. Namely, the Norwegian soccer players from the First league have a maximum oxygen consumption at about $62 \mathrm{ml} / \mathrm{min} / \mathrm{kg}$, New Zealander of $61 \mathrm{ml} / \mathrm{min} / \mathrm{kg}$, Australian about $60 \mathrm{ml} / \mathrm{min} / \mathrm{kg}$, Croatian $60 \mathrm{ml} / \mathrm{min} / \mathrm{kg}$, English 60 $\mathrm{ml} / \mathrm{min} / \mathrm{kg}$, the soccer players from Hong Kong $59 \mathrm{ml} / \mathrm{min} /$ $\mathrm{kg}$, soccer players from US $58 \mathrm{ml} / \mathrm{min} / \mathrm{kg}$, and top Brazilian players $52 \mathrm{ml} / \mathrm{min} / \mathrm{kg}$ (Sporis et al., 2017). On one hand, the conclusion is that Kosovian players have inferior aerobic abilities in comparison with the aforementioned data. It is certainly one of the reasons leading to lack of success of Kosovian soccer players in international matches where the opponent has prepared teams that play dynamic football and also represents a task for the professional teams to advance this important parameter using appropriate modern practice technologies. However, the example of soccer players from Brazilian First League shows that although this parameter is particularly important for the football game, it is not crucial for the success in top football. The team that has weaker aerobic abilities can modify game style but it takes the other potentials (anaerobic parameters, strategy, tactics, and technique) to be at the top level. Reilly et al. propose a specific threshold of $\mathrm{VO}_{2 \max }(60 \mathrm{ml} / \mathrm{min} /$ $\mathrm{kg}$ ), whereas in the case of values below this threshold will be considered that the player has no much chance of having the physiological attributes for success in top football. Also, $\mathrm{VO}_{2 \max }$ varies depending on the role and position of the player on the team. Gil et al. noted that $\mathrm{VO}_{2 \max }$ in 19 professional players in the Portuguese First League was below $60 \mathrm{ml} / \mathrm{min} / \mathrm{kg}$ for goalkeepers and defense players, and above $60 \mathrm{ml} / \mathrm{min} / \mathrm{kg}$ for the midfielders and attackers. These findings are similar to those for senior professional players in England, where players from midfield had significantly higher values of $\mathrm{VO}_{2 \max }$ than those of other positions (Reilly et al.). In a number of studies, differences in relative maximum oxygen consumption were not determined, regarding the position of the game. The authors suggest that the noted similarities between the players who 
play on different positions regarding the $\mathrm{VO}_{2 \max }$ may be due to the requirements imposed by the modern football, more movements of the attacking and defensive players. In this research there are no statistically significant differences in $\mathrm{VO}_{2 \max }$ between players who play defense, middle, and attack.

On the basis of the achieved results of this research, it can be concluded that there are no differences in anthropometric characteristics, somatotype components, and maximal oxygen consumption among other players who play in different positions on the team, except for the goalkeeper. The trend in modern football is increasingly focused on improving the performance of all players who play on all positions that will allow more movements both of attacking and defensive players. The undertaken roles among juniors and elite soccer players according to their positions are related to their physical performance. Somatotype is a method that estimates the physical profile in athletes. However, anthropometric and physiological factors are evaluated, together with genetic factors, and the effect of training. No single method is adequate to determine physical profile (Orhan et al.).

Talent selection and guidance is important in sports requiring high performance. Therefore, in talent selection, objective criteria should be used; and collective guidance should be used, based on anthropometric and physiologic tests. Appropriate guidance, based on individual differences and development, should be given priority (Orhan et al.).

Evaluation of somatotype components in this study indicate that there are no specifics in somatic typology of players who play in different positions on the team. Bearing in mind that football is one of the most popular sports in the world, during the selection of talented players, tests for assessing physiological and motor performance, together with anthropometric and somatotype research should be used and the players' development should be monitored.

\section{CONCLUSIONS}

In order to determine morphological and functional characteristics of young footballers from the Republic Kosovo and to analyze whether there are differences regarding the positions on which they play, there are 11 anthropometric measures which are applied for assessing longitude dimensionality, transversal dimensionality, voluminosity and fat tissue (skin folds), and indirectly the body composition, somatotype components and relative maximum oxygen consumption are measured.
Goalkeepers have statistically significantly higher body height and humeral breadth, and lower values of maximum oxygen consumption in comparison to players who play on other positions in the team and more weight regarding the players who play in the middle and forward. Defense players have statistically significantly higher body weight than the middle players. In the other anthropometric measures and somatotype components there are no statistically significant differences among the players who play on different positions in the team.

Our results suggest that the selection of players in football for individual playing positions must be based on morphological and functional characteristics of the players. Couches should have a good knowledge of general and specific tasks that the player should perform in the game. It is strongly recommended in top football for certain positions to choose players that are as much as possible compatible with the requirements of that playing positions according to their morphological and functional features.

The achieved results can serve as normative anthropometric indicators for regular sports medical examinations of young players in our country. The data can also be used as a template to compare anthropometric and somatotype data of young players from different countries.

GJONBALAJ, M.; GEORGIEV, G. \& BJELICA, D. Diferencias en las características antropométricas, los componentes del somatotipo y las habilidades funcionales entre jóvenes futbolistas de élite de Kosovo basadas en la posición en el equipo. Int. J. Morphol., 36(1):41-47, 2018.

RESUMEN: En el estudio se midieron la altura, peso, diámetros, volumen y pliegues cutáneos en una muestra de 242 jóvenes futbolistas de la República de Kosovo y se midieron indirectamente la composición corporal, los componentes del somatotipo, el índice de IMC y el consumo máximo de oxígeno para determinar sus características morfológicas y funcionales y para analizar la especificidad, es decir, las diferencias probables basadas en las posiciones de juego (porteros, defensa, jugadores medios y atacantes). Dentro del análisis estadístico, se calcularon los parámetros estadísticos descriptivos básicos, y se aplicaron análisis de varianza multivariante y univariado y el análisis post hoc. Los porteros estadísticamente tienen una altura mayor del cuerpo y de amplitud humeral, y valores más bajos de consumo máximo de oxígeno en comparación con los jugadores que juegan en las otras posiciones en el equipo y tienen un mayor peso corporal con respecto a los jugadores que juegan en el medio y los atacantes. Los jugadores de defensa tienen un peso corporal estadísticamente mayor que los jugadores del medio campo. En las otras medidas antropométricas y componentes del somatotipo, no existen diferencias estadísticamente significativas entre los jugadores que juegan en diferentes posiciones en el equipo. Los resultados logrados podrían servir como indicadores normativos morfológicos y fun- 
cionales para los exámenes médicos deportivos de los jugadores de fútbol en la República de Kosovo. También podrían usarse como una plantilla para comparar los datos morfológicos y funcionales de jugadores jóvenes de fútbol de niveles similares en diferentes países.

PALABRAS CLAVE: Composición corporal; Indicadores morfológicos y funcionales; Jugadores de fútbol.

\section{REFERENCES}

Bale, P. A review of the physique and performance qualities characteristic of games players in specific positions on the field of play. J. Sports Med. Phys. Fitness, 26(2):109-22, 1986.

Bandyopadhyay, A. Anthropometry and body composition in soccer and volleyball players in West Bengal, India. J. Physiol. Anthropol., 26(4):501-5, 2007.

Bangsbo, J. The physiology of soccer--with special reference to intense intermittent exercise. Acta Physiol. Scand. Suppl., 619:1-155, 1994.

Carter, J. E. L. \& Heath, B. H. Somatotyping - Development and Applications. 5th ed. Cambridge, Press Syndicate of the University of Cambridge, 1990.

Casajús, J. A. \& Aragonés, M. T. Estudio morfológico del futbolista de alto nivel. Composición corporal y somatotipo (Parte 1). Arch. Med. Deporte, 8(30):147-51, 1991.

Fidelix, Y. L.; Berria, J.; Ferrari, E. P.: Ortiz, J. G.; Cetolin, T. \& Petroski, E. L. Somatotype of competitive youth soccer players from Brazil. $J$. Hum. Kinet., 42:259-66, 2014.

Garstecki, M. A.; Latin, R. W. \& Cuppett, M. M. Comparison of selected physical fitness and performance variables between NCAA Division I and II football players. J. Strength Cond. Res., 18(2):292-7, 2004.

Gil, S. M.; Gil, J.; Ruiz, F.; Irazusta, A. \& Irazusta, J. Physiological and anthropometric characteristics of young soccer players according to their playing position: relevance for the selection process. J. Strength Cond. Res., 21(2):438-45, 2007.

Gontarev, S.; Kalac, R.; Zivkovic, V.; Ameti, V. \& Redjepi, A. Anthropometrical characteristics and somatotype of young macedonian soccer players. Int. J. Morphol., 34(1):160-7, 2016.

Hailu, E.; Kibret, E. \& Tomay, A. Assessment of anthropometric measurements and body composition of selected beginner South West Ethiopian soccer players. Turk. J. Sport Exerc., 18(2):56-64, 2016.

Hasan, A. A.; Rahaman, J. A.; Cable, N. T. \& Reilly, T. Anthropometric profile of elite male handball players in Asia. Biol. Sport, 24(1):3-12, 2007.

Ibrahim, M. M.; Singh, P. \& Kumar, H. Anthropometrical and physical performance profile of Ethiopian national league soccer players. Int. J. Sci. Res., 6(3):1364-7, 2017.

Matkovic, B. R.; Misigoj-Durakovic, M.; Matkovic, B.; Jankovic, S.; Ruzic, L.; Leko, G. \& Kondric, M. Morphological differences of elite Croatian soccer players according to the team position. Coll. Antropol., $27 \mathrm{Suppl}$. 1:167-74, 2003.

McIntyre, M. C. \& Hall, M. Physiological profile in relation to playing position of elite college Gaelic footballers. Br. J. Sports Med., 39(5):2646, 2005.

Orhan, O.; Sagir, M. \& Zorba, E. Comparison of somatotype values of football players in two professional league football teams according to the positions. Coll. Antropol., 37(2): 401-5, 2013.

Ostojic, S. M. Physical and physiological characteristics of elite Serbian soccer players. Facta Univ., 1(7):23-9, 2000.

Pluncevic-Gligoroska, J.; Todorovska, L.; Dejanova, B.; Maleska, V.; Mancevska, S. \& Nikolic, S. Anthropometric parameters in national footballers in the Republic of Macedonia. Pril (Makedon Akad Nauk
Umet Odd Med Nauki), 35(2):147-54, 2014

Pyne, D. B.; Gardner, A. S.; Sheehan, K. \& Hopkins, W. G. Positional differences in fitness and anthropometric characteristics in Australian football. J. Sci. Med. Sport, 9(1-2):143-50, 2006.

Reeves, S. Jr.; Poh, B.; Brown, M.; Tizzard, N. \& Ismail, M. Antropometric measurements and body composition of English and Malaysian footballers. Malays. J. Nutr., 5(1):79-86, 1999.

Reilly, T. \& Marfell-Jones, M. J. (Eds.). Kinanthropometry VIII. London, Routledge, 2003. pp.117-30.

Reilly, T.; Bangsbo, J. \& Franks, A. Anthropometric and physiological predispositions for elite soccer. J. Sports Sci., 18(9):669-83, 2000.

Rienzi, E.; Drust, B.; Reilly, T.; Carter, J. E. \& Martin, A. Investigation of anthropometric and work-rate profiles of elite South American international soccer players. J. Sports Med. Phys. Fitness, 40(2):1629, 2000.

Sporis, G.; Dujic, I.; Trajkovic, N.; Milanovic, Z. \& Madic, D. Relationship between morphological characteristics and match performance in junior soccer players. Int. J. Morphol., 35(1):37-41, 2017.

Thomas, V. \& Reilly, T. Fitness assessment of English league soccer players through the competitive season. Br. J. Sports Med., 13(3):103-9, 1979.

Ziv, G. \& Lidor, R. Physical characteristics, physiological attributes, and on-court performances of handball players: A review. Eur. J. Sport Sci., 9(6):375-86, 2009.

Corresponding author:

Msc. Malsor Gjonbalaj / Ph Candidate

University of Pristina

Faculty of Physical Education and Sport

Pristina

REPUBLIC OF KOSOVO

\section{Email: malsor.gjonbalaj@uni-pr.edu g_malsor@hotmail.com}

Received : 27-06-2017

Accepted : 24-10-2017 